\title{
Educational Financing in Canada 1970-71 to 1984-85: Who Calls the Tune, Who Pays the Piper?
}

\author{
ANNE MARIE DECORE and RAJ S. PANNU*
}

\begin{abstract}
This study examines changes in educational financing since 1970-71, looking at provincial differences in funding in relation to GDP, total government expenditures, enrolments and funding for elementary-secondary and tertiary schooling, as well as in relation to the funds contributed by each level of government. Since the late 1970's reductions have occurred in constant dollar per student expenditures at both elementary-secondary and university levels. In contrast to the early to late 1970's when provinces contributed ever larger proportions of the necessary funds, since that time both federal and municipal governments have been forced to increase their share of educational funding. These changes are examined not just in terms of intergovernmental relations but more importantly in terms of the fiscal crisis of the state.
\end{abstract}

\section{RÉSUMÉ}

Cette étude examine les changements dans le financement d'éducation depuis 1970-71, en examinant les différences provinciales dans la répartition des fonds par rapport au R.N.B.; la somme des dépenses gouvernementales, les inscriptions et la répartition des fonds pour l'éducation élémentaire, secondaire et tertiare; ainsi que la relation entre la somme des fonds versée, par chaque niveau gouvernemental. Les dépenses par étudiant en dollar constant ont diminué dès la fin des années soixante-dix aux niveau élémentaire-secondaire et universitaire. $A u$ début des années 70 , les provinces ont versé la majeure partie des fonds nécessaires. Par contraste, depuis cette époque le gouvernement fédéral et les gouvernements provinciaux ont étés forcés d'augmenter leurs parts des fonds pour l'éducation. Ces changements sont examinés non seulement sur le plan des relations intergouvernementales, mais plus important, sur le plan de la crise fiscale de l'état. 
For some years now, societies around the globe have been plagued by an endemic economic and social crisis. In advanced western capitalist societies the last decade, in particular, has been marked by stagnating economic growth, increasing unemployment, increasing inflation, and an associated social malaise. Of these, only inflation has recently slowed down. These problems, in turn, have led to contraction of state revenues, a fact that has created fiscal difficulties unknown to post-second world war governments. All of the advanced capitalist democracies including Canada have faced a serious fiscal crisis and most have responded with government policies of severe fiscal restraint. Attempts have been made either to cut back on the provision of public goods or services which have been a recognized part of the domain of government or to transfer part of the cost of such public goods to users. Examples of these public goods or services, which O'Connor (1973) labels "social capital", include outlays for education, health, culture, and the provision and maintenance of the economic infrastructure. ${ }^{1}$ The current spate of funding restraints for public goods or services in Canada should be understood in this broader context of change, and not simply in relation to the vagaries of shifting federal-provincial relations.

One of the major public expenditure outlays in Canada over the last twenty to thirty years has been for human capital development. For example in 1970 and for several years following, 8.5 to 9 percent of Canada's GNP was spent on education and training. In comparison, by $1983-84,7.8$ percent of GNP was spent on education and institutional training programs. As it has become clear that the economic and fiscal crisis will not simply go away, Canadian governments have sought ways of reducing their budgetary outlays for social welfare and for social consumption - in education, health, and culture. The current debate on educational financing that is raging in various quarters must be approached against this backdrop of the fiscal crisis of the state. Two recent examples of the concern about educational funding appear in Chapter 18, volume 2 of the Macdonald Commission Report on the Canadian economy (1985), and the Johnson Report on financing postsecondary education (1985).

Between 1970-71 and 1984-85, educational expenditures in Canada grew from about 7.6 billion dollars to 31.7 billion dollars (Statistics Canada, 1983, p. $12 ; 1985$, p. 37$)$. This represents an increase from 7.8 to 10.9 billion in constant (1971) dollars, a less impressive but still considerable growth in spending. During the same period, the number of full-time students in Canadian schools and postsecondary institutions declined from 5,961,300 to 5,757,500 (Statistics Canada, 1983, p. 178; 1985, p. 28). Rising costs in the face of apparently declining enrolments have prompted governments at all levels to attempt to control expenditures on education. Governmental concern about educational spending has been heightened by the rising incidence of unemployment and underemployment among well qualified Canadians, and by the economic recession of the 1980's. Attempts to restrain educational expenditure have been accompanied by disputes 
between the Federal and Provincial governments about cost sharing for postsecondary education. Indeed, agreement on a formula for postsecondary cost sharing to replace that embodied in the 1977 Federal-Provincial Fiscal Arrangements and Established Programs Financing Act was not reached for some time after it expired in 1982. At the elementary-secondary level there has also been contention about finance. In this case, Provincial governments have tried to constrain educational spending by limiting grants to local school boards and, in some cases, by placing limits on the ability of school boards to increase the amount of educational funds they derive from property taxation. In opposition to the restraints imposed on educational spending, educators, students, and parents are voicing concern about the quality and accessibility of education. In short, considerable debate has ensued from changes in the structure of enrolments and the accompanying changes in the financing of education as well as the shifts in the importance of different levels and programs that constitute the educational system.

While the global figures cited above give a general perspective on educational spending, they obscure important differences in expenditures and enrolments between provinces and between educational levels. For example, global data obscure the fact that expenditures per student vary considerably from province to province, or the fact that declining enrolments are the product of decreases at the elementary-secondary level while postsecondary enrolments have increased. Because education is an area of provincial jurisdiction, a focus on provincial comparisons is particularly important. In order to understand the current debate about educational spending, a number of specific questions must be addressed:

1. Has educational spending kept pace with general economic changes? More specifically, how do levels of educational expenditure in the provinces relate to their gross domestic product?

2. Have changes in educational expenditure increased or decreased proportionately to overall government expenditures?

3. How have enrolments changed within the various levels of education and what are the ramifications of these changes for explaining increases in educational expenditures?

4. Have the increases in educational expenditures occurred at a more or less uniform rate across different levels of Canadian educational systems? While it may be the case that educational expenditures have increased in all provinces, is it the case that those changes have similarly affected each level of education?

5. Do the figures on educational spending indicate that the unit costs of educating Canadians have dramatically increased?

6. Further, have there been changes during this period with respect to the distribution of educational spending between Federal, Provincial and Municipal governments?

Answers to these questions are not readily available, yet without them the debate about educational spending remains inconclusive and polemical. 


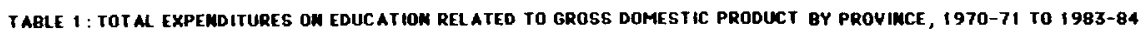

\begin{tabular}{|c|c|c|c|c|c|c|c|c|c|c|}
\hline YEAR & $\begin{array}{l}\text { British } \\
\text { / Columbia }\end{array}$ & I Alberta & /Saskatchewian/ & Manitoba / & Ontario & I Quebex & $\begin{array}{l}\text { New } \\
\text { / Brurs:swick }\end{array}$ & I Nora Scotia & $\begin{array}{c}\text { Prince } \\
\text { /Edward Island }\end{array}$ & New foundland \\
\hline $1970-71$ & 7.1 & 8.7 & 9.4 & 8.6 & 8.4 & 93 & 11.4 & 12.1 & 12.2 & 11.4 \\
\hline $1971-72$ & 6.9 & 8.6 & 8.5 & 87 & 8.1 & 97 & 113 & 113 & 140 & 12.2 \\
\hline $1972-73$ & 6.3 & 7.9 & 8.5 & 8.4 & 75 & 90 & 39 & 19.1 & 14.1 & 13.4 \\
\hline $1973-74$ & 5.7 & 6.6 & 7.3 & 7.7 & 5.5 & 9.3 & 90 & 9.6 & 13.1 & 12.5 \\
\hline $1974-75$ & 6.0 & 5.6 & 6.4 & 76 & 6.6 & 91 & 9.2 & 10.2 & 13.8 & 12.4 \\
\hline $1975-76$ & 6.8 & 5.8 & 6.7 & 7.7 & 6.8 & 35 & 3.9 & 10.5 & 12.6 & 13.7 \\
\hline $1976-77$ & 6.4 & 5.5 & 6.9 & 7.5 & 7.0 & 9.8 & 9.9 & 10.5 & 12.8 & 12.8 \\
\hline $1977-78$ & 6.4 & 6.0 & 7.2 & 8.1 & 7.4 & 105 & 10.4 & 10.3 & 12.5 & 12.3 \\
\hline $1978-79$ & 6.3 & 5.2 & 7.4 & 7.5 & 7.3 & 10.1 & 9.4 & 10.0 & 11.8 & 11.7 \\
\hline $1979-80$ & 5.9 & 5.0 & 6.5 & 7.4 & 70 & 99 & 8.7 & 100 & 11.8 & 11.3 \\
\hline $1980-81$ & 6.0 & 4.6 & 6.5 & 7.4 & 6.6 & 98 & (11) 2 & 10.9 & 12.1 & 12.4 \\
\hline $1981-82$ & 6.2 & 4.9 & 6.3 & 7.4 & 6.4 & 9.3 & 10.5 & 11.3 & 114 & 12.5 \\
\hline $1982-83$ & 6.8 & 5.5 & 7.2 & 80 & 6.9 & 9.5 & 110 & 110 & 115 & 12.8 \\
\hline $1983-84$ & 6.7 & 5.6 & 7.5 & 8.0 & 6.8 & 3.4 & 10.6 & 10.4 & 100 & 13.3 \\
\hline
\end{tabular}

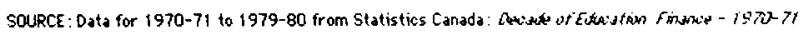
bo 1972000 Table 1, pp.14-35, 1983

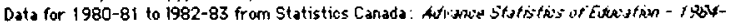
S5, Table 14, pp.36-37, 1985.

Data for 1983-84 calculated using expenditures given in Statistics Canada : Adilanis Stutistis:-

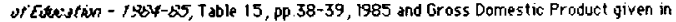

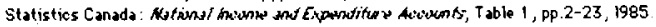

\section{Spending in Relation to GDP}

In order to understand changes in educational spending over time and differences between provinces in levels of expenditure one must look beyond dollar amounts. Since provinces differ in their economic resources and hence in their ability to finance education, an examination of educational spending in relation to the gross domestic product and to total government expenditures in a province gives a better indication of the relative importance attached to education in a province than does an examination of actual expenditures.

An examination of provincial expenditures on education in relation to provincial gross domestic product, given in Table 1 , reveals a number of interesting points. In every province, except Quebec and Newfoundland, educational spending in relation to GDP was lower in 1983-84 than it was in 1970-71. In fact, 1970-71 was the peak year for educational spending in relation to GDP in most provinces. Highest levels of spending relative to GDP occurred in 1971-72 for Manitoba, in 1973-74 for Prince Edward Island, in 1975-76 for Newfoundland, and in 1977-78 for Quebec. For all provinces then, recent spending is less than it was in the peak year.

In 1970-71, British Columbia spent less on education relative to GDP than any other province. At that time educational expenditures relative to GDP were highest in Nova Scotia. By 1983-84, Alberta became the lowest spender at 5.5\% of GDP 
IABLE 2 : EOUCATION EXPERDITURES* RELATED TO MET GOVERMMEMT EXPEMDITURES GY PROUIMCE, 1970-71 TO $1980-81$

\begin{tabular}{|c|c|c|c|c|c|c|c|c|c|c|}
\hline YEAR & $\begin{array}{c}\text { British } \\
\text { / Columbia }\end{array}$ & 1 Alberta & /5askatchewan! & Manitobd & 1 antario & 1 quebec & $\begin{array}{c}\text { New } \\
\text { / Brunswiak }\end{array}$ & / Nova Scotia & $\begin{array}{l}\text { Prine } \\
\text { Swars is }\end{array}$ & W foundiand \\
\hline 1970-71 & 27.8 & 30.8 & 28.1 & 26.6 & 33.8 & 29.3 & 26.8 & 28.6 & 22.5 & 23.1 \\
\hline $1971-72$ & 25.5 & 29.8 & 26.7 & 28.2 & 31.9 & 29.3 & 28.9 & 28.2 & 23.4 & 20.1 \\
\hline $1972-73$ & 24.5 & 29.6 & 26.0 & 27.5 & 30.2 & 27.7 & 25.9 & 27.2 & 23.2 & 19.5 \\
\hline $1973-74$ & 22.7 & 27.0 & 25.6 & 26.5 & 28.7 & 29.8 & 24.3 & 25.2 & 23.7 & 23.3 \\
\hline $1974-73$ & 22.4 & 23.6 & 23.0 & 24.7 & 26.4 & 27.8 & 23.9 & 26.2 & 24.3 & 22.3 \\
\hline $1975-76$ & 22.9 & 23.6 & 23.0 & 23.3 & 25.4 & 27.2 & 23.3 & 24.6 & 21.4 & 22.5 \\
\hline $1976-77$ & 23.2 & 20.6 & 22.6 & 22.5 & 26.9 & 28.4 & 23.6 & 26.6 & 24.6 & 22.6 \\
\hline $1977-78$ & 22.7 & 24.1 & 21.7 & 23.2 & 28.5 & 27.9 & 26.0 & 25.1 & 21.1 & 24.2 \\
\hline $1978-79$ & 23.1 & 20.2 & 22.2 & 23.0 & 27.9 & 26.6 & 24.4 & 24.6 & 20.4 & 18.8 \\
\hline $1979-80$ & 21.8 & 19.2 & 20.5 & 22.5 & 27.1 & 26.8 & 24.4 & 25.2 & 21.9 & 21.4 \\
\hline 1980-81 & 20.5 & 18.2 & 20.8 & 21.5 & 26.1 & 26.0 & 24.7 & 23.9 & 21.9 & 22.1 \\
\hline
\end{tabular}

*Government expenditures anly.

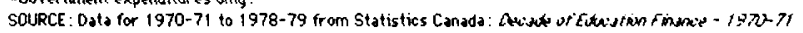
No 7072000 , Table 2, pp. 40-62, 1983

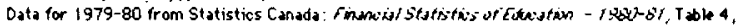
pp. 34-35, 1983.

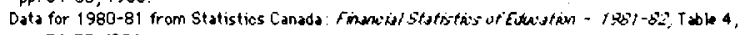
pp. 34-35, 1984

and Newfoundland the highest spender at $12.8 \%$ of GDP. Alberta is also the province in which the greatest decrease has occurred. Shifts such as these must, of course, be viewed with some caution. While they may be the product of changes in the degree of importance attached to education, they are also a reflection of changes in GDP per capita over time. Generally, the least affluent provinces those with the lowest GDP per capita, Quebec and the Atlantic provinces, have spent more on education relative to GDP than the more affluent. ${ }^{2}$

\section{Education Expenditures Relative to Total Government Expenditures}

Perhaps, a better indication of the priority given to education is the level of educational spending relative to total government expenditures because though not all provinces may be equally well off they may be similar in the relative resources they are willing to commit to it. Here too, one sees a pattern of decline. All provinces allocated a smaller proportion of their expenditures to education in 1980-81, the most recent year for which we obtained figures, than they did in 1970-71 (Table 2). Beyond this basic similarity, however, are interesting differences between the provinces. Some provinces have been relatively consistent in the proportion of their expenditures allocated to education. Prince Edward Island and Newfoundland have spent an average of about $22 \%$ of total government expenditures on education with small fluctuations over the time period. Ontario and to a lesser extent Quebec demonstrate a consistency of a different sort, in that they devote a larger share of provincial resources to education than the remaining provinces. 


\begin{tabular}{|c|c|c|c|c|c|c|c|c|c|c|}
\hline \multirow{3}{*}{$\begin{array}{l}\text { YEAR } \\
1970-71\end{array}$} & \multirow{3}{*}{$\begin{array}{c}\text { British } \\
\text { Columbia } \\
516,457\end{array}$} & \multirow{3}{*}{$\begin{array}{l}\text { Alberta } \\
424,954\end{array}$} & \multirow{2}{*}{\multicolumn{2}{|c|}{ 'Saskatchew an/ Manitoba }} & \multirow{3}{*}{$\begin{array}{l}\text { Cintario } \\
1,945.168\end{array}$} & \multirow{3}{*}{$\begin{array}{l}\text { Oupece } \\
1,534,544\end{array}$} & \multirow{3}{*}{$\begin{array}{c}\text { New } \\
\text { / Brunswick } \\
179.912\end{array}$} & \multirow{2}{*}{\multicolumn{3}{|c|}{$\begin{array}{c}\text { Prince } \\
\text { /Nova Scotis/Edward island New woundiand }\end{array}$}} \\
\hline & & & & & & & & & & \\
\hline & & & 245,517 & 239,120 & & & & 214,897 & 30,622 & 154,760 \\
\hline $1971-72$ & 514,377 & 426,718 & $24 !, 225$ & 236,678 & $1,956,786$ & $1,505,933$ & 175,977 & 214,780 & 30,570 & 156,374 \\
\hline $1972-73$ & 524,950 & 423,792 & $23:, 983$ & 231,409 & $1,949,154$ & $1,466,796$ & 173,851 & 211,262 & 29,340 & 155,414 \\
\hline $1973-74$ & 532.450 & 423,887 & 221,116 & 226,906 & $1,927,576$ & $1,417,507$ & 170,179 & 207,651 & 29,340 & 153,686 \\
\hline $1974-75$ & 523,840 & 424,965 & 218,441 & 221,560 & $1,909,268$ & $1,372,930$ & 166.550 & 204,280 & 28,149 & 151,758 \\
\hline $1975-76$ & 524,147 & 430,700 & 214,393 & 219,529 & $1,906,577$ & $1,328,149$ & 164,999 & 202,606 & 28,203 & 151,607 \\
\hline $1376-77$ & 518,705 & 432,184 & 212,194 & 217,234 & $1,8 \mathrm{R} 7,766$ & $1,275,263$ & 163,486 & 201,279 & 27,879 & 151,322 \\
\hline $1377-78$ & 510,621 & 430,818 & 205,646 & 213,154 & $1,867,109$ & $1,217,796$ & 152,202 & 198,097 & 27,610 & 149,978 \\
\hline $1978-79$ & 501,026 & 427,889 & 204,432 & 207,456 & $3,826,683$ & $1,170,193$ & 159.436 & 194,038 & 27,763 & 147,267 \\
\hline $1979-80$ & 494,522 & 424,523 & 200,736 & 200.653 & $1,783,317$ & $1,128,712$ & 156,280 & 189,225 & 27,258 & 144,653 \\
\hline $\mid 980-81$ & 492,054 & 425,002 & 197,450 & 194,477 & $1,752,106$ & $1,082,936$ & 152,183 & 185,568 & 26,834 & 142,922 \\
\hline $1981-82$ & 485,604 & 428,858 & 194,378 & 191,142 & $1,720,978$ & $1,052,615$ & 148.782 & 181,758 & 26,116 & 139,854 \\
\hline $1982-83 *$ & 462,273 & 435,457 & 193,372 & 192,606 & $1,706,360$ & $1,027,011$ & 147,878 & 179,554 & 25,723 & 137.224 \\
\hline $1983-84 *$ & 479,158 & 436,537 & 193,151 & 191,817 & $1,688,80$ & $1,020,100$ & 146,045 & 177,240 & 25,480 & 142,692 \\
\hline $1984-85 * p$ & 476,750 & 435,130 & 193.655 & 190,965 & $1,676,650$ & $1,019,150$ & 144,160 & 174,210 & 25,100 & 138,965 \\
\hline To change & $-76 \%$ & $2.4 \%$ & $-21.1 \%$ & $-20.1 \%$ & $-13.8 \overline{8}$ & -33.67 & $-18.0 \%$ & $-18.9 \%$ & $-18.0 \%$ & $-10.2 \%$ \\
\hline $\begin{array}{l}\text { *Adjusted fo } \\
\text { P Pretiminar } \\
\text { SOURCE : Dat } \\
0 \\
\text { Dat } \\
7 \\
\text { Dat } \\
\text { Pat }\end{array}$ & 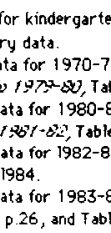 & $\begin{array}{l}\text { en enrolment } \\
1 \text { to } 1979-8 \\
\text { ble } 5, p p .12 \\
81 \text { and } 1981 \\
10, p p .48 \\
33 \text { from Stat } \\
84 \text { and } 1984 \\
\text { le } 6, p .28,1\end{array}$ & $\begin{array}{l}\text { tin accordance } \\
-80 \text { from Statist } \\
26-151,1983 . \\
1-82 \text { from Stat } \\
8-51,1984 \text {. } \\
\text { tistics Canada: } \\
\text { 4-85 from } \\
1985 \text {. }\end{array}$ & $\begin{array}{l}\text { with data for } \\
\text { tics Canada: } \\
\text { tistics Canada } \\
\text { Euterstion in }\end{array}$ & 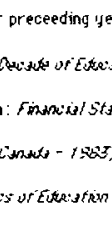 & 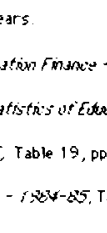 & $\begin{array}{l}-1272-71 \\
\text { destion- } \\
\text { pp.98-99, }\end{array}$ & & & \\
\hline
\end{tabular}

Although as indicated above all provinces decreased the proportion of funds expended on education, Alberta has done so most dramatically with a decrease from $30.8 \%$ to $18.2 \%$. Like Alberta, the other three western provinces fell into the category of low spenders. By 1980-81, British Columbia, Alberta, Saskatchewan and Manitoba were the four lowest spenders while only Manitoba was among the bottom four in $1970-71 .^{3}$

\section{Changes in Enrolment}

One possible explanation for government reluctance to maintain high levels of educational spending is, of course, the shrinking size of the school age population most likely to participate in educational programs. As was noted at the outset, there are now about 200,000 fewer students in Canadian educational institutions than there were in 1970 . We turn, therefore, to an examination of enrolments at various educational levels and their possible effects on educational expenditures.

Over the 1970-85 period, the absolute number of elementary and secondary students has steadily declined while the number of postsecondary students, both non-university and university, has noticeably increased. In other words, the 


\begin{tabular}{|c|c|c|c|c|c|c|c|c|c|c|}
\hline YEAR & $\begin{array}{c}\text { British } \\
\text { Columbia }\end{array}$ & $/$ Aiberta & ISaskatchewan' & Manitoba / & Ontario & Quebec I & $\begin{array}{c}\text { New } \\
\text { Brunswitck }\end{array}$ & $/$ Mora Scotiz & $\begin{array}{l}\text { Prince } \\
\text { Edward Islar }\end{array}$ & //Newfoundiand/ \\
\hline $1970-71$ & 31,673 & 31,577 & 15,868 & 19,090 & 135,722 & 80,924 & 11,933 & 16,448 & 2,060 & 7,196 \\
\hline $1971-72$ & 29,896 & 30,926 & 15,852 & 19,796 & 150,834 & 80,338 & 12,286 & 17,245 & 2,113 & 8,136 \\
\hline 1972-73 & 28,896 & 30,099 & 14,668 & 19,447 & 152,636 & 81,447 & 11,610 & 17,113 & 1,844 & 8,302 \\
\hline $1973-74$ & 30,321 & 31,283 & 15,112 & 19,783 & 160,393 & 82,508 & 11,941 & 17,609 & 1,711 & 7,509 \\
\hline $1974-75$ & 32,877 & 32,373 & 15,447 & 20,516 & 169,787 & 85,659 & 11,977 & 18,788 & 1,575 & 6,999 \\
\hline 1975-76 & 34,791 & 34,696 & 16,329 & 21,751 & 180,869 & 93,808 & 12,722 & 19,544 & 1,716 & 7,120 \\
\hline $1976-77$ & 34,579 & 35,021 & 17,074 & 21,683 & 184,909 & 96,204 & 12,334 & 19,959 & 1,722 & 7,556 \\
\hline $1977-78$ & 33,984 & 34,729 & 17,192 & 21,228 & 181,795 & 103,724 & 12,379 & 20,156 & 1,771 & 7,709 \\
\hline $1978-79$ & 33,966 & 33,888 & 16,669 & 20,178 & 177,292 & 107,174 & 12,091 & 19,827 & 1,623 & 7,077 \\
\hline 1979-80 & 34,776 & 33,478 & 16,582 & 19,448 & 178,747 & 113,180 & 12,111 & 19,570 & 1,539 & 7,602 \\
\hline $1980-81$ & 35,762 & 34,850 & 16,899 & 19,835 & 185,307 & 118,122 & 12,355 & 20,015 & 1,528 & 7,870 \\
\hline $1981-82$ & 37,195 & 37,276 & 18,225 & 21,354 & 193,926 & 120,743 & 13,361 & 21,425 & 1,613 & 8,756 \\
\hline 1982-83 & 39,040 & 41,194 & 20,193 & 23,750 & 203,580 & 125,340 & 14.472 & 22,988 & 1,785 & 10,154 \\
\hline 1983-84 & 40,300 & 44,583 & 21,721 & 25,317 & 211,045 & 132,877 & 15,441 & 25,119 & 1,882 & 9,212 \\
\hline 1984-85p & 43,020 & 47,614 & 22,997 & 26,554 & 219,143 & 137,271 & 16,303 & 25,150 & 1,960 & 10,117 \\
\hline 7 change & 36.3 象 & $508 \%$ & 44.98 & 39.18 & 61.58 & 69.68 & $36.6 \%$ & $65.3 \%$ & $-4.9 \%$ & $40.6 \%$ \\
\hline \multicolumn{11}{|c|}{ 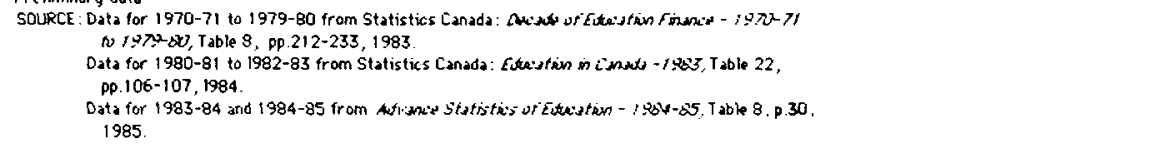 } \\
\hline
\end{tabular}

proportion of the total student population in each level of schooling in Canada has undergone considerable change.

As Table 3 shows, all provinces, except Alberta, have experienced a decline in elementary-secondary enrolments since 1970-71. The most dramatic decrease has occurred in Quebec where the number of students declined by $33.6 \%$, a total decline of 515,394 students. ${ }^{4}$ Decreases in the remaining provinces range between $7.6 \%$ in British Columbia and $21.1 \%$ in Saskatchewan.

The picture given in Table 4 with regard to both full and part-time university enrolments is a dramatic contrast to that above. Over the period 1970-71 to 1984-85, full-time equivalent (FTE) enrolments in Canadian universities have increased by nearly 200,000 students to a total of 552,320 students. In most provinces, there have been small year-to-year fluctuations, both up and down, in university FTE enrolments but the overall pattern is one of increase. Only Prince Edward Island has experienced a decrease of $4.9 \%$ but all other provinces have showed increases of over 35\%. Most remarkable are the increases in Quebec at $69.6 \%$ (56,347 students), Nova Scotia at 65.3\% (10,739 students), and Ontario at $61.5 \%(83,421$ students).

Although in absolute terms, there are 222,520 more university students than non-university postsecondary students in Canada and the numerical growth over 


\begin{tabular}{|c|c|c|c|c|c|c|c|c|c|c|}
\hline \multirow{3}{*}{$\begin{array}{l}\text { PEAR } \\
1970-71\end{array}$} & \multirow{3}{*}{$\begin{array}{c}\text { British } \\
\text { Columbia } / \\
13,010\end{array}$} & \multirow[b]{2}{*}{ Alber $t$} & \multirow[b]{2}{*}{ /Saskatchew wn } & \multirow{3}{*}{$\begin{array}{l}\text { Manitob } \\
3,377\end{array}$} & \multirow{3}{*}{$\begin{array}{l}\text { Ontario } \\
54,399\end{array}$} & \multirow{3}{*}{$\begin{array}{l}1 \text { Quedec I } \\
74,375\end{array}$} & \multirow{3}{*}{$\begin{array}{c}\text { New } \\
\text { Brunswick } \\
2,694\end{array}$} & \multirow{2}{*}{\multicolumn{3}{|c|}{$\begin{array}{l}\text { Prince } \\
\text { /Mova Scotia/Edward Island/Mew foundland/ }\end{array}$}} \\
\hline & & & & & & & & & & \\
\hline & & 11,443 & 2,151 & & & & & 2,855 & 350 & 1,420 \\
\hline $1971-72$ & 12,823 & 12,672 & 2,436 & 3,808 & 50,345 & 84,209 & 2,506 & 2,893 & 584 & 1.548 \\
\hline $1972-73$ & 12,618 & 13,330 & 2,461 & 3,370 & 52,521 & 100,227 & 1,969 & 2,477 & 490 & 1.491 \\
\hline $1973-74$ & 13,298 & 13,590 & 2,523 & 2,789 & 55,399 & 107,609 & 1,236 & 2,509 & 860 & 1,638 \\
\hline $1974-75$ & 16,571 & 14,091 & 2,347 & 2,792 & 56,642 & 112.132 & 1,187 & 2,690 & 842 & 1,861 \\
\hline 1975-76 & 16.579 & 15,263 & 2,397 & 3,177 & 59,640 & 117,663 & 1,309 & 2,394 & 708 & 1,964 \\
\hline 1976-77 & 16,638 & 16,431 & 2,387 & 3,434 & 58,919 & 121,095 & 1,454 & 3,007 & 752 & 2,024 \\
\hline 1977-78 & 17,086 & 16,962 & 2,415 & 3,154 & 60,994 & 133,803 & 1,564 & 2,877 & 760 & 2,050 \\
\hline $1978-79$ & 17,444 & 17,411 & 2,397 & 3,110 & 64,499 & 137,753 & 1,656 & 2.768 & 770 & 1,960 \\
\hline 1979-80 & 17,108 & 17,872 & 2,375 & 3,057 & 70,164 & 134,185 & 1,791 & 2,793 & 782 & 2,019 \\
\hline 1980-81 & 17,953 & 17,900 & 2,412 & 3,459 & 75,846 & 135,405 & 1,888 & 2,919 & 820 & 2,225 \\
\hline $1981-82$ & 18,477 & 18,795 & 2,559 & 3.556 & 80,605 & 141.456 & 1,963 & 2,713 & 894 & 2,384 \\
\hline 1982-83 & 20,610 & 20,790 & 2,472 & 3,609 & 89,326 & 150,234 & 2,162 & 2,834 & 905 & 2,576 \\
\hline $1983-84$ & 22,720 & 21,720 & 2,830 & 3,730 & 97,550 & 157,300 & 2,270 & 2,920 & 940 & 2,520 \\
\hline $1984-85^{P}$ & 23,800 & 22,800 & 3,000 & 3,870 & 103,600 & 163,600 & 2,360 & 3,020 & 1,010 & 2,630 \\
\hline$\$ 8$ change & $82.9 \%$ & 99.28 & $39.5 \%$ & 14.68 & $90.4 \%$ & 120.08 & $-12.4 \%$ & $5.8 \%$ & $188.6 \%$ & $85.2 \%$ \\
\hline $\begin{array}{l}\text { PPreliminat } \\
\text { SOURCE: } D \\
\text { Data for } 19\end{array}$ & $\begin{array}{l}y \text { data. } \\
\text { ta for } 1970-7 \\
\text { os } 7979-50, T \\
80-81 \text { to } 1982 \\
1984\end{array}$ & $\begin{array}{l}\text { to } 1979-8 \\
\text { ple } 7 \text {, pp. } \\
33 \text { from } 5\end{array}$ & $\begin{array}{l}80 \text { from Statistics } \\
190-211,1983 \\
\text { Statistics Canda : }\end{array}$ & Es Canad & indext & Stanting & $106-$ & & & \\
\hline
\end{tabular}

the 1970-71 to 1984-85 period has been greater in the university sector, there has been an impressive growth in the non-university enrolments. It should be noted here that part-time non-university enrolments are not available so the data used here underestimate the growth that has occurred over the fifteen-year period examined. Unlike the enrolments in university, the growth of non-university enrolments is very uneven from province to province (Table 5). Only four provinces experienced substantial numerical and percentage growth in enrolments. In British Columbia and Alberta, the numerical growth exceeds 10,000 students. As might be expected, the growth in Ontario is very large at over 49,000 students, and the growth in Quebec is even more dramatic at over 89,000 students. ${ }^{5}$

As this brief overview demonstrates, while elementary-secondary school enrolments have fallen over the past fifteen years, the postsecondary level presents a contrasting picture of growth amounting to an explosion of enrolment in both forms of postsecondary education, particularly in the provinces of British Columbia, Alberta, Ontario and Quebec. Given that the costs of university and non-university postsecondary education are higher than those for other levels of education, it is not at all surprising that educational expenditures have soared all across Canada. What is surprising is that educational expenditures relative to 
GDP and total government expenditures have fallen. Based on the observed increases in postsecondary university and non-university programs, along with declining enrolments at the elementary-secondary level, it is reasonable to expect that there would be some reallocation of expenditures from the primary and secondary sector to the tertiary sector over the fifteen-year period examined here. ${ }^{6}$

\section{The Distribution of Funds Between Educational Levels}

In Table 6 we present the proportion of funds spent on each level of education including expenditures by Federal, Provincial, and Municipal governments - to discern whether the allocation of resources has shifted in accordance with changes in enrolments in elementary-secondary, university, non-university, and vocational occupational sectors. It should be noted at the outset of this discussion that in talking about expenditures, we are looking at the proportional distribution of funds between levels of education and that in talking about enrolments we are looking at changes in enrolment within each level. ${ }^{7}$ In spite of this, it is reasonable to expect that as enrolments decline or increase within any particular sector, that change would eventually be reflected in the allocation of resources between sectors.

As indicated in the preceding section, enrolments at the elementary-secondary level were lower in 1984-85 than in 1970-71 in every province but Alberta. Despite this fact, Table 6 shows that the proportion of total educational expenditures that went to this level increased in every province but Quebec. In the case of Nova Scotia, $48.9 \%$ of all educational expenditures went to elementarysecondary education in 1970-71, however, by 1984-85 this had increased to $63.5 \%$ despite the fact the number of students at this level had declined by $18.9 \%$. Although this is the most extreme case, the pattern is the same in other provinces ranging from Newfoundland where elementary-secondary expenditures increased by 8.6 percentage points over the time period, to British Columbia where the increase was only 0.9 percentage points.

Having established that the share of expenditures for elementary-secondary education increased over the fifteen years examined and that, therefore, the share for tertiary education decreased; the question of how the relative spending between university, non-university, and vocational-occupational programs is distributed remains. No single pattern of distribution is evident.

The proportion of funds expended on both postsecondary and vocationaloccupational education decreased between 1970-71 and 1984-85 in the provinces of Nova Scotia, Prince Edward Island and Newfoundland. ${ }^{8}$ Quebec, in contrast, shows increased spending for non-university education, with $6.8 \%$ of total educational expenditures in 1970-71 and $13.5 \%$ in 1984-85 going to this level. The share of expenditures going to universities also increased, but by a smaller amount, from $17.1 \%$ of the total to $18.7 \%$.

A still different pattern obtains in the remaining six provinces with increases in the proportion of funds for non-university postsecondary education and decreases in the proportion of funds for university and vocational-occupational education. 
IABLE 6 : DISTRIBUTION OF EXPENDITURES BETYEEN EDUCATIONAL LEVELS BY PROVIMCE, 1970-71 TO 1984-85

\begin{tabular}{|c|c|c|c|c|c|c|c|c|c|c|c|c|c|c|c|c|c|c|c|c|}
\hline \multirow[t]{3}{*}{ 'YEAR. } & \multirow{3}{*}{$\begin{array}{l}f_{0} B \\
\text { elem } \\
\text { sect }\end{array}$} & \multicolumn{2}{|c|}{$\begin{array}{l}\text { ritish Columbia } \\
\text { non- }\end{array}$} & \multicolumn{2}{|c|}{ i } & \multicolumn{2}{|c|}{$\begin{array}{l}\text { Alberta } \\
\text { non- }\end{array}$} & \multicolumn{2}{|c|}{1} & \multicolumn{3}{|c|}{$\begin{array}{l}\text { Saskatchewar } \\
\text { non- }\end{array}$} & & \multicolumn{2}{|c|}{$\begin{array}{l}\text { Manitoba } \\
\text { non- }\end{array}$} & \multicolumn{2}{|c|}{1} & \multicolumn{2}{|c|}{$\begin{array}{l}\text { Onturio } \\
\text { non- }\end{array}$} & \multirow{3}{*}{$\begin{array}{l}\text { roc- } \\
\text { oce }\end{array}$} \\
\hline & & univ & univ & voor & elem & univ & univ & Yoc- & elem & univ & & & elem & univ & unir & yoc- & elem & unir & uniy & \\
\hline & & $\begin{array}{l}\text { post } \\
\text {-sec }\end{array}$ & & 000 & $-\sec$ & $\begin{array}{l}\text { post } \\
\text {-sec }\end{array}$ & & 000 & $-\sec$ & $\begin{array}{l}\text { post } \\
\text {-sect }\end{array}$ & & $0<0$ & $-\sec$ & post & & $a c c$ & $-\sec$ & post & & \\
\hline $1970-71$ & 64.2 & 4.6 & 22.1 & 9.1 & 59.5 & 45 & 27.7 & 8.3 & 66.2 & 16 & 21.3 & 10.9 & 65.3 & 2.2 & 24.8 & 7.7 & 61.3 & 6.2 & 26.1 & 6.4 \\
\hline $1971-72$ & 63.2 & 6.2 & 230 & 76 & 59.2 & 7.4 & 26.9 & 6.7 & 65.4 & 2.3 & 23.3 & 90 & 66.6 & 2.6 & 24.0 & 68 & 53.2 & 6.7 & 25.0 & 5.1 \\
\hline $1972-73$ & 66.2 & 6.5 & 21.0 & 6.3 & 61.1 & 7.1 & 24.5 & 6.7 & 66.5 & 2.4 & 22.2 & 8.5 & 65.3 & 2.4 & 25.5 & 6.8 & 64.8 & 6.5 & 23.4 & 5.3 \\
\hline $1973-74$ & 56.5 & 6.7 & 20.3 & 6.5 & 64.3 & 5.2 & 22.0 & 6.9 & 67.2 & 2.7 & 21.6 & 8.5 & 86.0 & 1.9 & 25.4 & 6.7 & 65.0 & 6.2 & 24.2 & 4.6 \\
\hline $1974-75$ & $6 \in 0$ & 7.3 & 200 & 6.7 & 63.3 & 7.3 & 21.1 & 8.3 & 68.2 & 2.7 & 21.0 & 7.8 & 65.2 & 1.9 & 25.6 & 6.3 & 65.1 & 6.3 & 24.0 & 4.6 \\
\hline $1975-76$ & 65.0 & 7.8 & 19.6 & 70 & 61.7 & 7.1 & 21.9 & 9.3 & 67.5 & 3.7 & 21.7 & 7.1 & 65.0 & 3.0 & 25.4 & 6.6 & 65.1 & 6.4 & 23.8 & 4.7 \\
\hline $1976-77$ & 67.0 & 7.8 & 18.4 & 68 & 64.1 & 7.2 & 22.1 & 6.6 & 69.7 & 3.2 & 21.5 & 56 & 67.1 & 2.6 & 23.0 & 7.3 & 66.2 & 6.0 & 22.0 & 58 \\
\hline $1977-78$ & 68.1 & 7.1 & 18.7 & 6.1 & 67.5 & 7.5 & 17.0 & 60 & 69.3 & 3.8 & 21.4 & 5.5 & 67.4 & 2.8 & 22.7 & 7.1 & 68.4 & 5.7 & 20.9 & 5.0 \\
\hline $1978-79$ & 67.4 & 7.9 & 18.4 & 6.3 & 62.5 & 8.8 & 20.9 & 7.8 & 68.5 & 3.9 & 22.0 & 56 & 70.0 & 2.4 & 21.1 & 6.5 & 68.5 & 6.6 & $20 . \epsilon$ & 4.3 \\
\hline 1979-80 & 66.4 & 8.5 & 18.7 & 6.4 & 62.4 & 8.7 & 20.5 & 8.4 & 69.0 & 3.7 & 21.4 & 5.9 & 69.7 & 2.7 & 21.2 & 6.4 & 68.9 & 6.9 & 20.0 & 4.2 \\
\hline $1980-81$ & 65.4 & 8.5 & 19.5 & 6.6 & 61.4 & 9.3 & 21.1 & 8.1 & 69.0 & 3.7 & 21.4 & 5.9 & 71.0 & 2.4 & 20.7 & 5.8 & 67.5 & 7.0 & 21.0 & 4.5 \\
\hline $1981-82$ & 65.9 & 8.8 & 19.6 & 6.3 & 61.9 & 9.1 & 20.8 & 8.2 & 67.0 & 3.8 & 20.7 & 8.4 & 69.9 & 2.8 & 21.1 & 6.2 & 67.5 & 6.9 & 20.8 & 4.8 \\
\hline $1982-83^{p}$ & 67.8 & 7.7 & 17.8 & 6.6 & 61.3 & 9.2 & 21.7 & 7.6 & 68.5 & 4.0 & 19.4 & 8.1 & 69.1 & 2.1 & 19.6 & 6.4 & 66.7 & 7.2 & 21.3 & 4.6 \\
\hline $1983-84^{\circ}$ & 65.3 & 8.9 & 18.2 & 7.5 & 62.4 & 8.8 & 20.8 & 7.9 & 69.2 & 4.2 & 19.3 & 73 & 68.8 & 2.7 & 21.4 & 7.1 & 66.9 & 7.1 & 21.1 & 4.8 \\
\hline $1984-85^{e}$ & 65.1 & 9.1 & 18.5 & 7.3 & 62.5 & 8.9 & 20.1 & 8.2 & 690 & 4.1 & 19.2 & 7.6 & 69.3 & 2.7 & 21.3 & 6.8 & 67.1 & 7.0 & 21.1 & 4.8 \\
\hline
\end{tabular}




\begin{tabular}{|c|c|c|c|c|c|c|c|c|c|c|c|c|c|c|c|c|c|c|c|c|}
\hline \multirow[t]{3}{*}{ VEAR } & \multirow{2}{*}{ elem } & \multicolumn{2}{|c|}{$\begin{array}{l}\text { Queties } \\
\text { non- }\end{array}$} & 1 & \multicolumn{3}{|c|}{$\begin{array}{l}\text { New Bruns wick } \\
\text { non- }\end{array}$} & \multicolumn{2}{|c|}{7} & \multicolumn{2}{|c|}{$\begin{array}{l}\text { Nova Scotia } \\
\text { rori- }\end{array}$} & s & \multicolumn{3}{|c|}{$\begin{array}{l}\text { Prince Edward Is land } \\
\text { non- }\end{array}$} & \multicolumn{2}{|l|}{ d } & \multicolumn{2}{|c|}{$\begin{array}{l}\text { New foundland } \\
\text { non- }\end{array}$} & \multirow{3}{*}{$\begin{array}{l}\text { roce } \\
\text { ooc }\end{array}$} \\
\hline & & univ & urris & $4 x-$ & elem & univ & univ & roc- & elern & univ & urive & roc- & elem & univ & univi & vor- & elem & univ & univ & \\
\hline & & post & & oec & $-5 e c$ & post & & occ & $-\sec$ & post & & oce. & $-\sec$ & post & & 000 & $-\sec$ & post & & \\
\hline $1970-71$ & 70.4 & 6.8 & 17.1 & 5.7 & 64.0 & 3.0 & 22.2 & 10.8 & 48.9 & 3.5 & 33.6 & 14.0 & 59.6 & 4.0 & 20.4 & 140 & 56.7 & 2.9 & 21.0 & 19.4 \\
\hline $1971-72$ & 70.3 & 7.8 & 156 & 6.3 & 56.2 & 3.1 & 20.6 & 10.1 & 540 & 3.4 & 30.5 & 12.1 & 58.0 & 5.1 & 21.9 & 150 & 58.3 & 3.6 & 23.5 & 14.6 \\
\hline $1972-73$ & 67.7 & 9.2 & 16.4 & 6.7 & 63.6 & 3.2 & 21.8 & 11.4 & 59.4 & 3.2 & 25.4 & 12.0 & 59.4 & 4.6 & 22.3 & 13.7 & 57.3 & 3.1 & 24.6 & 14.9 \\
\hline $1973-74$ & 67.3 & 10.5 & 158 & 6.4 & 64.3 & 2.5 & 226 & 10.6 & 60.1 & 3.4 & 24.4 & 12.1 & 61.8 & 4.3 & 20.1 & 13.8 & 60.4 & 3.4 & 23.1 & 13.1 \\
\hline $1974-75$ & 66.5 & 10.9 & 17.0 & 5.6 & 65.9 & 20 & 23.4 & 8.7 & 57.6 & 3.0 & 28.3 & 11.1 & 66.2 & 5.2 & 16.2 & 12.4 & 63.8 & 3.6 & 20.3 & 12.3 \\
\hline $1975-76$ & 65.9 & 11.3 & 17.4 & 5.4 & 64.2 & 1.8 & 23.4 & 10.6 & 56.5 & 3.4 & 27.5 & 126 & 62.1 & 5.4 & 16.5 & 16.0 & 624 & 3.4 & 21.1 & 13.1 \\
\hline $1376-77$ & 68.5 & 10.8 & 15.8 & 4.3 & 66.9 & 2.3 & 21.3 & 9.5 & 61.7 & 3.6 & 23.3 & 11.4 & 67.4 & 4.8 & 13.0 & 14.8 & 64.7 & 3.5 & 20.4 & 11.4 \\
\hline $1977-78$ & 66.1 & 11.5 & 17.1 & 5.3 & 69.2 & 2.3 & 18.9 & 9.6 & 62.1 & 4.3 & 23.6 & 10.0 & 65.5 & 5.8 & 12.5 & 16.2 & 63.7 & 2.7 & 220 & 11.6 \\
\hline $1978-79$ & 65.2 & 12.6 & 17.6 & 4.6 & 67.9 & 26 & 20.2 & 9.3 & 62.2 & 3.1 & 24.9 & 9.4 & 64.3 & 6.5 & 13.6 & 15.6 & 65.8 & 2.6 & 20.8 & 10.8 \\
\hline 1979-60 & 66.0 & 116 & 17.8 & 4.6 & 66.9 & 3.2 & 21.2 & 9.7 & 62.3 & 3.0 & 25.4 & 9.3 & 65.4 & 6.5 & 14.9 & 13.2 & 67.1 & 2.9 & 19.8 & 10.2 \\
\hline $1980-81$ & 66.4 & 11.8 & 17.4 & 4.4 & 66.9 & 3.5 & 21.4 & 8.2 & 61.7 & 3.8 & 25.5 & 9.0 & 66.4 & 6.0 & 14.2 & 13.4 & 56.0 & 2.8 & 20.6 & 10.6 \\
\hline $1981-82$ & 56.8 & 12.8 & 16.7 & 4.3 & 68.2 & 3.4 & 20.7 & 7.7 & 62.4 & 2.8 & 26.4 & 8.4 & 670 & 5.4 & 150 & 12.6 & 676 & 2.3 & 19.2 & 10.9 \\
\hline $1982-83^{\circ}$ & 64.1 & 13.3 & 18.3 & 46 & 68.5 & 3.7 & 20.3 & 7.5 & 64.8 & 27. & & 7.9 & 66.2 & 21.7 & & 12.1 & 67.2 & & 2.6 & 10.2 \\
\hline $1983-84^{\mathrm{e}}$ & 64.5 & 13.2 & 17.9 & 4.4 & 67.7 & 4.5 & 19.4 & 3.4 & 64.4 & 27 & 8 & 78 & 650 & 22.8 & & 12.5 & 70.9 & & 9.5 & 9.6 \\
\hline $1984-85^{e}$ & 62.6 & 13.5 & 18.7 & 5.2 & 67.2 & 4.4 & 20.2 & 8.2 & 63.5 & 28 & & 8.1 & 61.3 & 27.9 & & 10.8 & 65.3 & & 1.7 & 13.0 \\
\hline \multicolumn{21}{|c|}{ Pprelimiriary data } \\
\hline \multicolumn{21}{|c|}{ 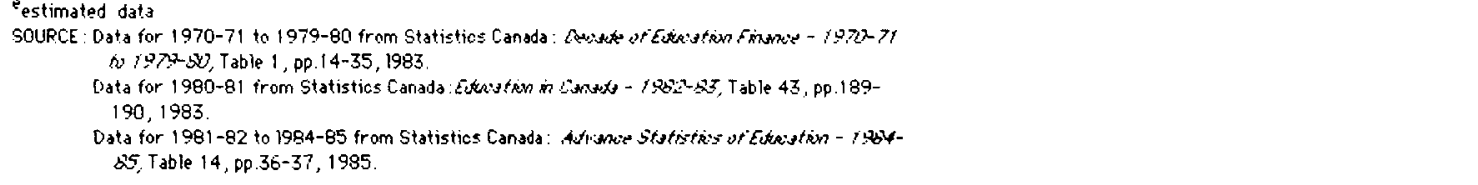 } \\
\hline
\end{tabular}


TARL 7 : EL EMENT ARY-GECOND ARY EXPEMDITURES PER GTUDENT IN CONST ANT ${ }^{\circ}$ DOLL ARS

\begin{tabular}{|c|c|c|c|c|c|c|c|c|}
\hline YEAR. & $\begin{array}{c}\text { Oritish } \\
/ \text { Columbia }\end{array}$ & I Alberta $/$ & /Saskatchewan/ & / Manitoba / & Dotario & 1 Duebec & $\begin{array}{l}\text { Pter } \\
\text { Bruns }\end{array}$ & is wick \\
\hline $70-71$ & 771740 & 853 b423 & $7337 / 2$ & 799777 & $9443 / 5$ & $894 \times 60$ & 666 & $5+7$ \\
\hline $71-72$ & 821 & 908 & 753 & 883 & 1002 & 1001 & 727 & \\
\hline $72-73$ & 834874 & 947 ירי & $791 \quad 5: 29$ & $896 \times 53$ & $1019 / 2 \times 65$ & 952 प्र & 673 & 7205 \\
\hline $73-74$ & 875 206 & $96511205^{\circ}$ & : 834 서이 & $920 / 1257$ & $101711 * 6$ & $1061 / 186$ & 691 & 777 \\
\hline $74-75$ & 9901230 & 9871234 & / $890 / / 12$ & $978 / 22$ & $103712 \%$ & $1124 / 425$ & 789 & 286 \\
\hline $75-76$ & $1098 / 52 \%$ & $1067 / 478$ & $980 / 357$ & $104014 \times 0$ & $10621+71$ & 12191008 & 848 & 1178 \\
\hline $76-77$ & $1195 / 730$ & 11261676 & 1099 /637? & $1090 / 623$ & $1199 / 736$ & 15222386 & 934 & $13 \% 1$ \\
\hline $177-78$ & 124720205 & 13802210 & 112413830 & 1192 1917 & 13472706 & 1638.2635 & 1038 & $150 \%$ \\
\hline $78-79$ & 1277237 & $1189=2034$ & $1163=2337$ & $1206: 3 / 3$ & $1350: 2365$ & $1631265 i$ & 973 & 1704 \\
\hline $79-80$ & 12872060 & 12602410 & 1184263 & 12562001 & $138128 \times 0$ & 17053260 & 987 & 15356 \\
\hline $80-81$ & 15723310 & 14803117 & 13582060 & $1367: 287$ & 14503254 & $1921+020$ & 1084 & 28. \\
\hline $81-82$ & 1478302 & $1393 \leq 320$ & 12983075 & 130250254 & 13655235 & $1859+557$ & 1050 & 245 \\
\hline $82-83 *$ & 1345 종 & $12725350^{\circ}$ & 12833367 & $131037 \times 0$ & $12305: 38$ & $1745+58 \%$ & 1090 & 2036 \\
\hline \multicolumn{9}{|c|}{ 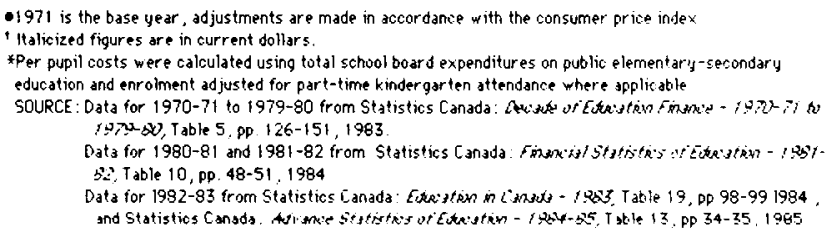 } \\
\hline
\end{tabular}

BY PRovince, 1970-71 10 $1982-83$

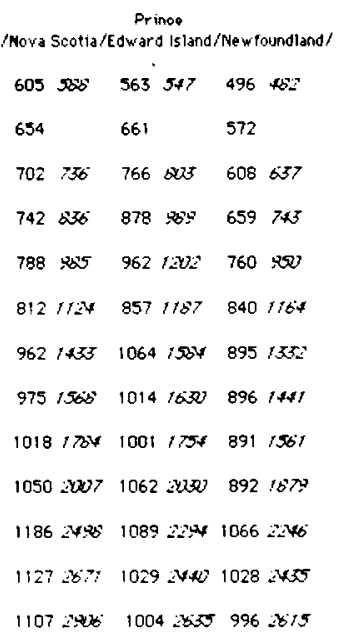

The largest increase in the postsecondary non-university share occurred in British Columbia (up from $4.6 \%$ to $9.1 \%$ of the total) and Alberta (up from $4.5 \%$ to $8.9 \%$ of the total). Outside of Quebec, these two provinces and Ontario spend a larger proportion of educational funds on this level than other provinces, a reflection of enrolment factors noted above and perhaps of provincial government policy priorities.

It is the shifts in the relative funding of university education that stand out in terms of consistency and, in some cases, in terms of size. Only in Quebec has the proportional allocation of funds reflected the enrolment shifts that have occurred between 1970-71 and 1984-85; in all other provinces the share of funds going to elementary-secondary education has increased despite enrolment declines. ${ }^{9}$ In other words, as enrolments in non-university programs, most notably in British Columbia, Alberta and Ontario, have risen so has the share of funds going to such programs. This has not been the case with regard to university programs where the share of educational funds allocated has generally decreased despite rising enrolment. Most dramatic is the case of Alberta which allocated $27.7 \%$ of its educational expenditures to universities in $1970-71$ but only allocated $20.1 \%$ in 1984-85. 


\section{Funding per Student}

It might, of course, be argued that the great university building boom of the 1960's and early 1970's has meant lower capital expenditures in the late 1970's and 1980's. The declining share of educational expenditures for the university sector may, therefore, be the product of smaller capital expenditures and not of decreases in operating funds. By examining operating expenditures per student, the following anaylsis looks at the impact on elementary-secondary and university education of changes in both the proportional distribution of funds between educational levels/programs and the changes in enrolment.

To examine the impact of the redistribution of funds between educational levels discussed above, complete data on enrolments by level are needed. Such data are available for two levels only - elementary-secondary and university. For this reason, this analysis is confined to an examination of changes in operating costs (in constant dollars) per pupil for schools and per FTE (full-time equivalent) for universities for the period of 1970-71 to 1982-83.

A rapid growth in per pupil expenditures at the elementary-secondary level took place between 1970-71 and 1980-81 (Table 7). In fact, in 1980-81 per pupil costs were the highest of any year for the period under discussion for all provinces except Prince Edward Island. The above ten year period was also one of unbroken growth for every province except New Brunswick and Newfoundland. Moreover, by 1980-81 British Columbia, Quebec and Newfoundland had each more than doubled its per pupil cost over the decade.

The turning point wạs 1980-81. Without exception, every province registered a reduction in these expenditures. Further reductions were made the following year, and again in 1982-83, the most recent year for which complete data are available. The sole exception is New Brunswick. Thus a clear trend signalling cross-Canada cutbacks in per pupil expenditures at the elementary-secondary level seems to have emerged in recent years. It needs to be noted, even though it should be obvious, that this reduction in per pupil expenditures is independent of any fluctuation in enrolments. It would appear to have been the result of a more general policy shift, the latter related perhaps to fiscal concerns of Canadian governments and to a shift in perception of the benefits of investments in education.

The provincial picture in terms of university operating expenditures per FTE is somewhat similar to that for elementary-secondary expenditures (Table 8). Although there is less similarity across provinces as to when the more or less continuous pattern of cuts in expenditures for a particular province began, a clear trend indicating a systematic expenditure rollback is discernible. In 1970-71, Ontario started ahead of every other province with a per FTE expenditure of $\$ 3,495$, followed closely by British Columbia and Alberta respectively. The remaining provinces, with perhaps the exception of Nova Scotia, roughly cluster together a fair distance behind.

It is noteworthy that, for Ontario, 1970-71 was the peak year. In the subsequent twelve years, it has cut back fairly consistently reaching the third lowest position in 
TABLE : UNIVERSITY OPERATIMG EXPEMDITURES PER TTE IN CONSTANT DOLLARE BY PROVINCE 1970-71 TO 1982-83

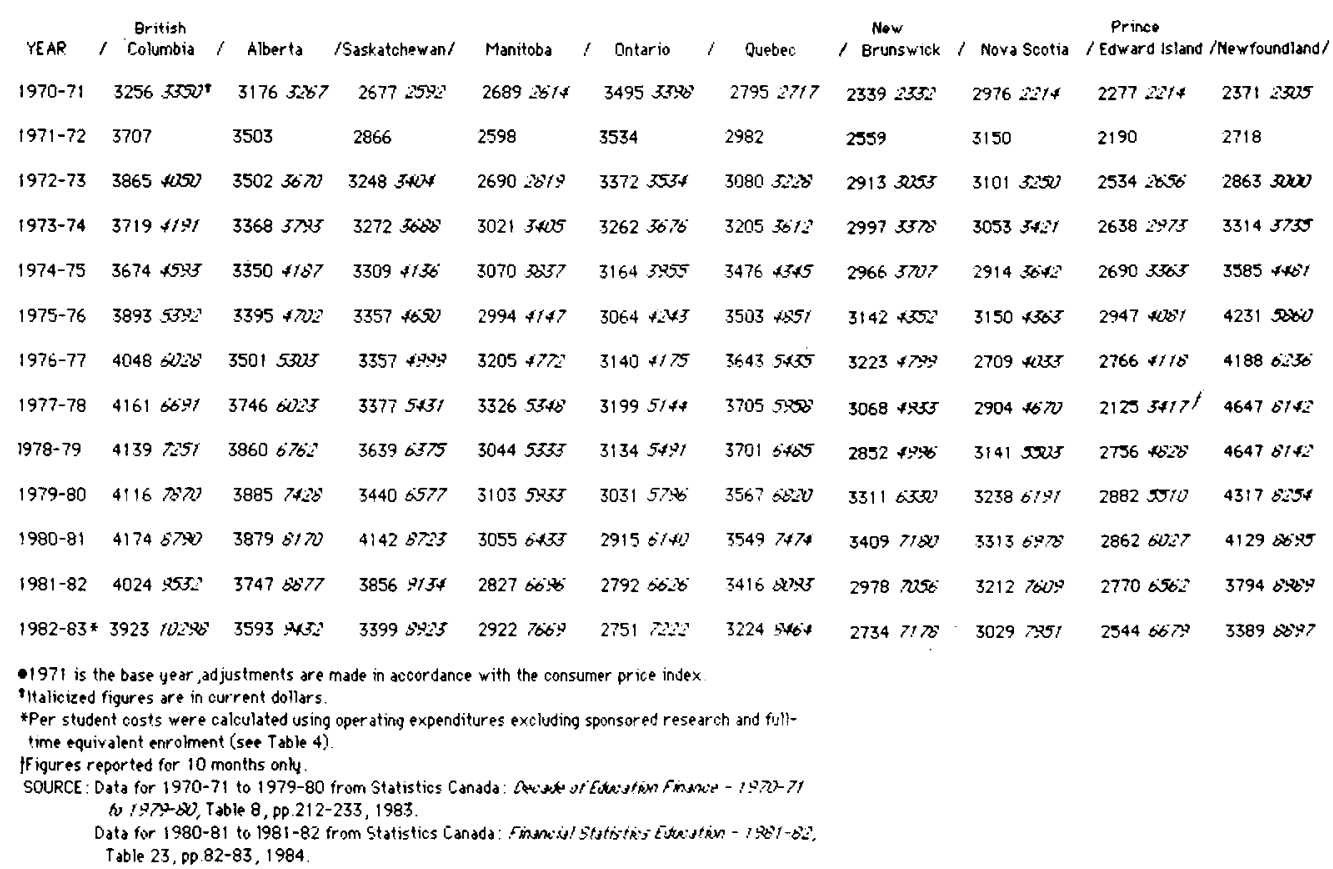


the country in 1982-83. Interestingly, this early lead in cutbacks was not heeded by other provinces till well after the mid-1970's. By 1980-81, however, cutbacks became universal and continued on into the subsequent years. Of particular note is the fact that, despite the generalized provincial cutbacks just mentioned above, Ontario is the only province which achieved a substantial reduction $(21.2 \%)$ in its $1982-83$ per FTE expenditures $(\$ 2,751)$ over its $1970-71$ expenditures $(\$ 3,495)$.

It is evident that cutbacks in university expenditures had become a fact of life throughout Canada by the late 1970's and continued into the 1980's. Whether expenditures will level off before reaching a level lower than that which prevailed in each province in 1970-71, or follow the lead of Ontario remains to be seen.

In the absence of part-time enrolment data for non-university postsecondary level one can only conjecture how per FTE expenditures have changed over the period after $1970-71 .^{10}$ Given that those provinces with rising full-time enrolments in non-university programs have not reduced the proportion of their total educational expenditures to the non-university sector, the likelihood is that the impact of government restraint has not been as great as in the university sector.

The analysis of spending undertaken here reveals a general pattern of progressive cutbacks in educational expenditures at both educational levels examined. During the period since 1982-83, educational institutions have felt the impact of continued attempts by provincial governments to control educational spending. The per student expenditures for elementary-secondary and university levels give convincing evidence that the indications of decrease derived from both the per cent of GDP data and the per cent of expenditures data are not simply a reflection of declining enrolment, rapidly rising GDP or rapidly rising total government expenditures. They represent net decreases in operating expenditures.

\section{Total Educational Expenditures - Federal, Provincial and Municipal Shares}

Changes in educational expenditures in Canada during the period since 1970 have been manifold. As demonstrated below, this includes a steady though gradual shift in the relative shares of different levels of government - federal, provincial and municipal. Since the 1960's, a major proportion of educational expenditures in Canada has typically been met from provincial government revenues. Provincial government revenues for education, however, come from two sources: provincial taxation and other provincially based sources of revenue and indirect federal transfers for postsecondary education and minority language programs.

At the elementary-secondary level, educational expenditures are shared principally by the provincial and municipal governments, although some direct funding even for this level comes from the federal level (Table 9). With respect to the relative provincial and municipal shares, the provinces tend to group into two neat clusters. With the exception of Nova Scotia, the Atlantic provinces as well as Quebec from 1970-71 onwards have borne a very high share of these expenditures from provincial revenues. In Newfoundland and New Brunswick over all of the 
last 15 years the provincial share has been over $85 \%$ of elementary-secondary expenditures. Other members of this cluster have all experienced rapid growth in this respect. In other words, either the provincial share was already high in $1970-71$ or it has progressively grown into the $80 \%+$ range in 1984-85. Because of these high provincial shares, the municipal contributions are correspondingly low.

In the provinces of Ontario, Manitoba, Saskatchewan, Alberta and British Columbia, members of the second cluster, the municipal share of direct educational expenditures for the elementary-secondary level has been noticeably higher. For instance in 1970-71, it ranged from a low of 36.3\% for Alberta to a high of $44.9 \%$ for Manitoba. Over the period, 1970 to 1985 , the earlier years are marked by a general tendency for the municipal share to drop in relation to the provincial share and then, from roughly 1976 on, to increase. Especially since 1980-81, there is a discernible trend for the provincial share to become smaller in Alberta, Ontario and, to a lesser extent, Saskatchewan. In the case of Manitoba, to the contrary, the provincial share jumped by about 6.6 percentage points while at the same time municipal share is reduced by a similar proportion.

From these shifts in the relative provincial and municipal shares of direct expenditures on elementary-secondary education, it appears that in the second cluster of provinces an increasing burden of funding is being shifted to the municipal governments and, thus, to property owners rather than to income earners generally. This would seem to hold particularly in the cases of Ontario, Saskatchewan and Alberta. British Columbia was certainly in this league as well, but only until 1981-82. A much slower and smaller change has been witnessed in the Federal share in these provinces. It has generally tended to shrink but shrinkage has been the least in the case of Ontario and Saskatchewan. Even the largest decrease, in Manitoba, has not exceeded $4 \%$.

The foregoing analysis yields several interesting observations on the pattern of changes in educational expenditures over the last decade and half. Major variations across provinces in their respective share notwithstanding, the percentage share of each province showed a consistent tendency to increase throughout the decade of $1970-71$ to $1980-81$. Past this point in time, this uniformity in trend or direction of change disappears. On the one hand, the Atlantic provinces and the province of Quebec show a continuing movement towards a modest growth in provincial share. On the other hand, Ontario and the Western provinces, with the exception of British Columbia, are on a downward course and if that trend were to continue their respective shares would certainly slide below the 1970-71 levels in the next couple of years.

While only some provinces show an increase in the proportion of elementarysecondary expenditures borne by municipal authorities, a much clearer shift in which level of government bears the cost is evident in the case of postsecondary education (Table 10). In every province, except Quebec, the provincial share of postsecondary costs has declined while the federal share has increased. Although 
TABLE 10 : ADJUSTED FEDERAL \& PROYINCIAL EXPEMDITURE SHARES FOR POST-geCOMDARY EDuCation GY PROVINCE, 1970-71 ro 1982-83

\begin{tabular}{|c|c|c|c|c|c|c|c|c|c|c|c|c|c|c|c|c|c|c|c|c|}
\hline \multirow[b]{2}{*}{ VEAR: } & \multicolumn{2}{|c|}{ British } & \multirow{2}{*}{\multicolumn{2}{|c|}{ I Alberta }} & \multirow{2}{*}{\multicolumn{2}{|c|}{ Sosth atche wan! }} & \multirow{2}{*}{\multicolumn{2}{|c|}{ Manitaba }} & \multirow{2}{*}{\multicolumn{2}{|c|}{1 Ontorio }} & \multirow{2}{*}{\multicolumn{2}{|c|}{ If Suebec }} & \multicolumn{2}{|c|}{ New } & \multicolumn{6}{|c|}{. Prince } \\
\hline & $\begin{array}{l}1 \text { colu } \\
\text { Fed. }\end{array}$ & $\begin{array}{l}\text { mbia } \\
\text { Proy. }\end{array}$ & & & & & & & & & & & $/$ Bruns & $\begin{array}{l}\text { Swetick } \\
\text { Prov }\end{array}$ & $\begin{array}{l}\text { Novas } \\
\text { Fed }\end{array}$ & $\begin{array}{l}\text { Scotia } \\
\text { Proy }\end{array}$ & Fedward & $\begin{array}{l}\text { Island } \\
\text { Prax }\end{array}$ & $\begin{array}{l}\text { Newiour } \\
\text { Fed }\end{array}$ & $\begin{array}{l}\text { indland! } \\
\text { Prow. }\end{array}$ \\
\hline $970-71$ & 50.2 & 31.8 & 447 & 39.0 & 58.4 & 26.8 & 53.1 & 27.0 & 39.9 & 40.3 & 579 & 15.1 & 48.4 & 27.4 & 39.9 & 25.4 & 50.4 & 44.9 & 55.6 & 29.4 \\
\hline $1971-72$ & 50.2 & 28.7 & 44.7 & 410 & 54.9 & 23.9 & 540 & 29.1 & 440 & 35.2 & 643 & 156 & 56.0 & 21.1 & 47.8 & 22.3 & 47.1 & 35.8 & 49.7 & 36.2 \\
\hline $1972-73$ & 59.4 & 25.3 & 48.6 & 37.5 & 58.9 & 208 & 54.0 & 316 & 479 & 316 & 65.4 & 16.7 & 57.3 & 23.3 & 60.6 & 178 & 43.0 & 31.2 & 61.4 & 26.1 \\
\hline $1973-74$ & 58.5 & 22.7 & 55.6 & 310 & 618 & 21.9 & 56.2 & 28.0 & 48.3 & 31.5 & 649 & 13.2 & 00.7 & 21.3 & 600 & 10.4 & 46.3 & 21.6 & 49.7 & 38.3 \\
\hline $974-75$ & 52.3 & 27.3 & 52.7 & 322 & 58.4 & 24.3 & 52.7 & 31.8 & 49.1 & 311 & 60.1 & 22.4 & 56.7 & 25.8 & 51.4 & 25.2 & 53.5 & 33.4 & 52.9 & 35.3 \\
\hline $1975-76$ & 46.8 & 29.6 & 48.2 & 42.0 & 51.6 & 33.7 & 52.9 & 35.6 & 49.8 & 319 & 58.2 & 25.3 & 53.0 & 20.0 & 55.1 & 20.4 & 54.8 & 33.3 & 50.1 & 42.0 \\
\hline $1976-77$ & 51.9 & 26.6 & 49.8 & 36.6 & 55.4 & 32.6 & 61.3 & 25.8 & 50.4 & 31.8 & 505 & 27.7 & 61.2 & 18.0 & 57.0 & 18.9 & 64.9 & 27.9 & 54.9 & 36.8 \\
\hline $1977-78$ & 63.7 & 17.9 & 52.7 & 33.7 & 65.5 & 17.6 & 66.4 & 22.4 & 560 & 25.9 & 48.7 & 386 & 82.1 & 3.3 & 55.8 & 15.8 & 89.6 & 10.0 & 68.2 & 16.8 \\
\hline $1978-79$ & 65.2 & 19.3 & 53.0 & 34.4 & 54.9 & 17.3 & 77.9 & 7.4 & 57.7 & 24.5 & 48.5 & 38.4 & 86.8 & 0.4 & 66.3 & 14.2 & 85.4 & 2.9 & 81.9 & 8.5 \\
\hline $1979-80$ & 65.7 & 19.5 & 53.4 & 32.5 & 70.3 & 12.9 & 78.3 & 5.4 & 60.0 & 20.8 & 489 & $37: 1$ & 83.8 & -0.7 & 68.3 & 75 & 83.0 & -3.5 & 84.2 & 6.5 \\
\hline $1980-81$ & 64.6 & 14.8 & 575 & 29.5 & 65.0 & 13.0 & 81.2 & 2.1 & 61.9 & 17.2 & 55.6 & 39.5 & 78.5 & 2.1 & 11.5 & 6.1 & 87.1 & -3.0 & 83.7 & 73 \\
\hline $81-82$ & 62.6 & 15.9 & 57.3 & 29.5 & 68.0 & 14.7 & 77.8 & 50 & 63.7 & 15.2 & 48.3 & 39.6 & 78.3 & 4.9 & 689 & 7.4 & 90.7 & -6.6 & 81.7 & 5.7 \\
\hline $\begin{array}{l}\text { * Adjuste } \\
\text { tr ansf } \\
\text { subtr } \\
\text { SOURCE: }\end{array}$ & $\begin{array}{l}\text { ers and } \\
\text { cted from } \\
\text { Data for } \\
\text { If to } 1 \\
\text { Date for }\end{array}$ & $\begin{array}{l}n \text { the p } \\
1970- \\
0772-80 \\
1980-\end{array}$ & $\begin{array}{l}\text { to } \\
\text { to } 19\end{array}$ & $\begin{array}{l}\text { share. } \\
79-80 \\
, p D .16 \\
2-83 \mathrm{fr}\end{array}$ & $\begin{array}{l}\text { from Sta } \\
68-189 \\
\text { from Sta }\end{array}$ & $\begin{array}{l}\text { aper at } \\
\text { toistics } \\
1983 . \\
\text { tistics }\end{array}$ & anada: & apit & $\begin{array}{l}\text { ixpenditur } \\
\text { of Eustess }\end{array}$ & $\begin{array}{l}\text { Federal } \\
\text { res. } \\
\text { thes ing }\end{array}$ & inance & 10,00 & & & & & & & & \\
\hline
\end{tabular}


there is considerable variation in the actual proportions from province to province, there is a consistent decrease in provincial share everywhere but Quebec. Quebec, in 1970-71, contributed a smaller proportion (15\%) than any other province. At the other extreme, Prince Edward Island assumed $44.9 \%$ of postsecondary costs at the beginning of the 70's. By 1981-82 a complete reversal had occurred, with Quebec assuming the largest provincial share and Prince Edward Island the smallest. In the West, the decreases range between 9.5 percentage points in Alberta and 22 percentage points in Manitoba. In Ontario and the Atlantic provinces the decreases are larger and range between 18 percentage points in Nova Scotia and 51.5 percentage points in Prince Edward Island.

An examination of the federal contributions, of course, shows parallel increases in the share of postsecondary expenditures assumed by the national government. While the federal share ranged between $39.9 \%$ in Ontario and $58.4 \%$ in Saskatchewan in 1970-71, the spread increased with a federal share of $48.3 \%$ in Quebec and $90.7 \%$ in Prince Edward Island by 1981-82. It is clear that through successive federal-provincial funding agreements, not only did federal funding increase in dollar amounts but also in relative terms. Indeed, Johnson's data on federal transfers to the provinces for postsecondary education between 1977-78 and 1984-85 clearly reinforces the point that the indirect federal contribution to grants to universities and colleges has grown while the purely provincial share has correspondingly declined. By 1984-85, the dollar value of fiscal transfers received by the provinces of Newfoundland, New Brunswick, Prince Edward Island, Manitoba and British Columbia was greater than the total expenditures for postsecondary education in those provinces. (Johnson, 1985, p. 30). Except in Quebec, improvements in federal funding for postsecondary education have been, partially if not wholly, offset by lower dollar levels of funding from provincial governments. "

The consequences of these changes have been predictable. Real expenditures per FTE have been dropping since 1978 or 1979 . University tuition fees, expressed in constant dollars, have been rising in every province except Quebec since 1981-82. Vital services like research equipment, computer and library services are falling behind, and universities have begun to resort to enrolment limitations and staff redundancy in the name of preserving financial solvency and quality programming.

\section{Findings and Policy Implications}

During the period since $1970-71$, educational spending relative to GDP has declined in every province but Newfoundland. Similarly, educational expenditures relative to net government expenditures have decreased in all ten provinces. Particularly in the case of the latter measure, the decreases have been largest in Ontario and the Western Provinces.

Except in Alberta, 1984-85 elementary-secondary enrolments are lower than in 1970-71 with the largest decline of $33.6 \%$ in Quebec. Despite these decreases, 
the distribution of funds between educational levels shows that in 1984-85, for all provinces but Quebec, a larger share of total educational funds went to elementary-secondary education than was the case in 1970-71. There has, however, been either a stabilization or a small shrinkage in the elementarysecondary share in the eighties. Consistent with this, constant dollar per student expenditures which rose quite evenly through the 1970's have, since 1980-81, shrunk in all provinces.

In contrast, university enrolments, except in Prince Edward Island, have increased between $36.2 \%$ (B.C.) and $69.6 \%$ (Que.). Non-university postsecondary enrolments also increased in all provinces save New Brunswick. Particularly large percentage and numerical increases in both university and non-university students are evident in British Columbia, Alberta, Ontario and Quebec. The corollary of the increased share of educational funds going to elementary education has been a decline in the postsecondary share of funds, again with the exception of Quebec. Within the postsecondary sector, those provinces that experienced increased non-university enrolments also demonstrate increases in the proportion of educational expenditures for that form of education. Most of the overall decrease in the share of expenditures for postsecondary education has then occurred at the expense of university education. While it was not possible to calculate per student FTE expenditures for non-university programs, the figures for university education show a clear pattern of decrease in every province since at least 1980-81 and as early as 1971-72 in Ontario.

Recently declining per student expenditures for both elementary-secondary and university education give some indication of attempts to constrain educational spending in the face of the fiscal crisis faced by governments. An examination of the financial contributions of various levels of government casts this problem in a particularly interesting light, as it reveals the provincial governments' fiscal footwork. In the case of elementary-secondary education, the provincial share in Quebec and the Atlantic provinces was at, or has increased to, the $80 \%$ level and beyond. In the remaining provinces, the provincial share gradually increased until the late 1970's but not to the high proportions of Quebec and the Atlantic Region. Since then, the provinces of Alberta, Ontario and to a lesser extent Saskatchewan have shifted some of the financial burden to municipalities. The sudden increase in 1982-83 in provincial contribution of British Columbia for elementary-secondary education appears to be an exception to this trend. It may however represent a different approach to controlling expenditures by having the provincial government assume a larger share of the costs in order to exert greater overall control on spending and eventually reduce it by limiting the degree of financial latitude of locally elected school boards. This intention became clear in 1985 when some school boards tried to maintain higher per pupil expenditures and were dismissed by the Minister of Education.

A shift in who pays the piper has occurred in much clearer terms for postsecondary education. This study, like Johnson's (1985), shows that from 1970-71 and especially after 1977, a larger and larger share of the burden of 
financing postsecondary education has fallen to the Federal government. Only Quebec comes near maintaining a constant share after 1977.

Several strategies are evident here for dealing with government fiscal problems: real decreases in the level of per student funding for educational services; some increases in the users' contributions; and a reduction, at least for Provincial governments, in the costs of providing education by shifting an increasing share of funding to other levels of governments. In a nutshell, these measures taken in concert are apparently designed to reduce or stabilize per pupil operating costs to governments.

However, operating costs, or that portion of them most susceptible to manipulation by state policies, are largely composed of employee remuneration. Since the majority of educational operating funds are expended for salaries, decreases in the constant dollar per student expenditures are a clear reflection of a two-pronged attempt to reduce the size of the labour force so employed and their salary levels. An associated but politically less attractive option is to shift at least a portion of the cost of these services to the user. For example, extra charges to parents for books, equipment, sports programs are being implemented in some jurisdictions. In a recent case, in Alberta, a local school board sued a parent for unpaid fees for school books - and lost.

\section{Concluding Observations}

Sustained cutbacks in social consumption and social investment expenditures have emerged as typical responses to the budgetary problems spawned by stagnating economic growth, increasing unemployment, and shrinking state revenues concomitant with rising expenditures and growing deficits. Solving these problems means rearranging the social and economic priorities of the state and its institutional components.

Social expenditures in such areas as education and health are seen by most Canadians as social entitlements and by their governments as important for the social stability requisite to capital accumulation and growth in productivity and production. ${ }^{12}$ Because of this, the fiscal crisis cannot be solved simply by dismantling those programs that provide minimal social welfare services, health care, protection against unemployment, and relatively open accessibility to education. If withdrawal of these services is not politically feasible, what options are open for the state to solve its fiscal problems? The most attractive option would seem to be to reduce the costs of the services provided by the state without significantly reducing their level of provision.

If costs are to be reduced, then the institutional complex that provides social services must be "reformed" and made more "efficient". It is the complementarity of public perceptions and of structural imperatives for economic growth that has been employed by the state and governing political parties as a basis for a "new consensus" in order to attack the problems of the fiscal crisis. The changes in educational financing we have discussed above and the politics of educational reform are directly linked to and can best be understood in terms of the 
simultaneous requirements for social stability and redeployment of fiscal resources. In light of the logic of this argument and the findings of our analysis, increased pressure on expenditures for both elementary-secondary and university education can be expected in the coming years. Together, all the above changes have global ramifications for the key issues of accessibility, private costs of going to school for students and their families; the structure of educational revenues of different public educational jurisdictions or enterprises; and the taxation regimes of the three levels of government with responsibility for financing of education.

\section{NOTES}

1. O'Connor discusses "social capital" expenditures both conceptually and substantively in Chapters 4 and 5 of his book. Armstrong accurately summarizes this view as follows:

O'Connor starts his book with two premises concerning the advanced capitalist state: first, the state 'must try to fulfill two basic and often mutually contradictory functions - accumulation and legitimation'; second, ... state spending has a twofold character corresponding to these functions, with social capital expenditures and social expenses fulfilling the accumulation and legitimation functions respectively. The social capital expenditures are further subdivided into social investment expenditures on physical and 'human capital' and social consumption expenditures, notably for urban-suburban development and for social insurance.

O'Connor then puts forward two theses: first, 'the growth of the state is both a cause and an effect of the expansion of monopoly capital' and, second, that the growth of state expenditures and state expenses results in a fiscal crisis, or structural gap, between state spending and state revenues, a crisis exacerbated by the successful yet wasteful and even contradictory claims made on the state by a host of special interests, including organized labour and the poor. (1977, p. 292.)

2. In the case of Alberta, the period of 1970-71 to the early 1980's was a period of boom in the oil industry and hence of rapid growth in the gross domestic product. Over the period from 1970-83, Alberta's GDP, which was second only to Ontario's in 1970, at \$4,490 per capita grew to $\$ 24,020$. The magnitude of this growth becomes evident when contrasted with that of Newfoundland which grew from $\$ 2,311$ per capita to $\$ 9,448$ over the same period. (Calculated from Statistics Canada: Provincial Economic Accounts, Table 1, pp. 4-23, 1985 and Statistics Canada: Post-Censal Annual Estimates of Population, Table 1, p. 29, 1985.)

3. It might be argued, of course, that Alberta's overall budget could and did grow more rapidly than was the case elsewhere, however, looking at the growth of overal provincial government expenditures over the time period the rate of expenditure growth in Alberta is not out of line with that of other provinces although it is the highest. Alberta's expenditures grew by $570 \%$ between 1970 and 1983, but expenditures in the provinces of British Columbia, Newfoundland and Prince Edward Island also increased by over $500 \%$ and expenditures increased by more than $400 \%$ in all other provinces except Ontario. (Expenditure growth calculated from Statistics Canada: Provincial Economic Accounts, Table 2, pp. 4-23, 1985.)

4. Part of this decrease reflects the fact that the equivalent of the twelfth grade is offered in the Collèges d'enseignement général et professionnel which are classified as non-university postsecondary institutions.

5. This growth in Quebec reflects the significant reorganization of education initiated in the 1960's, and particularly the development of the CEGEPS.

6. A complete examination of changes in educational enrolments would, ideally, include a look at vocational- occupational programs; unfortunately, such information is not available after the mid-1970's. While anecdotal evidence indicates that vocational-occupational enrolments have increased, the scope of that increase cannot be specified. 
Educational Financing in Canada 1970-71 to 1984-85:

7. Two factors dictate this approach: the differences in the costs of various levels of education mean that the proportion of funds will not necessarily correspond to the proportion of all students that are enrolled at particular level, and comparable enrolment data are not available for all types of education.

8. For Nova Scotia, Prince Edward Island, and Newfoundland postsecondary university and non-university expenditures are aggregated for the three most recent years perhaps because the non-university component is not a large part of the postsecondary total. For Nova Scotia, the shift in distribution between the elementary-secondary level and the tertiary level is not surprising because of the low proportion of funds going to elementary- secondary education in 1970-71, $48.9 \%$ of the total, and the high proportion going to university education, $33.6 \%$.

9. As the Economic Council of Canada notes in its Fifteenth Annual Report, "Part of the increase can be explained by the drop in the student-teacher ratio ... in secondary schools - a phenomenon largely related to the widened variety of courses being offered and to the assignment of counselling and other non-teaching tasks to teachers." (1978, p. 107.) Generally, reapportionment of educational funds for postsecondary non-university education has better reflected enrolment in such programs than has been the case for university programs.

10. Part-time non-university enrolments are not available from either Statistics Canada sources or for most provinces from their published educational statistics.

11. Johnson, pp 2-3.

12. See the Council of Ministers of Education, Changing Economic Circumstances: The Challenge for Postsecondary Education and Manpower Training, and Government of Alberta, White Paper: Proposals for an Industrial and Science Strategy for Alberta - 1985 to 1990.

\section{REFERENCES}

Armstrong, H. "The Labour Force and State Workers," in L. Panitch (ed.), The Canadian State. Political Economy and Political Power. Toronto: University of Toronto Press, 1977.

Council of Ministers of Education. Changing Economic Circumstances: The Challenge for Postsecondary Education and Manpower Training. October, 1985.

Deaton, R. "The Fiscal Crisis of the State in Canada," in D. Roussopoulos (ed.), The Political Economy of the State. Montreal: Black Rose Books, 1973, pp. 18-58.

Economic Council of Canada. A Time for Reason. Ottawa: Supply and Services, Fifteenth Annual Review, 1978.

Government of Alberta. White Paper: Proposals for an Industrial and Science Strategy for Alberta-1985 to 1990. Edmonton: July, 1984.

Johnson, A.W. Giving Greater Point and Purpose to the Federal Financing of Postsecondary Education and Research in Canada. Ottawa: Secretary of State, 1985.

O'Connor, J. The Fiscal Crisis of the State. New York: St. Martin's Press, Inc., 1973.

Royal Commission on the Canadian Economy. Economic Union and Development Prospects for Canada. Ottawa: Supply and Services, 1985.

Statistics Canada. Advance Statistics of Education - 1985. Ottawa: Supply and Services, 1985.

Statistics Canada. Decade of Educational Finance - 1970-71 to 1980-81. Ottawa: Supply and Services, 1983.

Statistics Canada. Post-Censal Annual Estimates of Population. Ottawa: Supply and Services, 1985.

Statistics Canada. Provincial Economic Accounts. Ottawa: Supply and Services, 1985. 